\title{
Coercive measure-sequestration for environmental crime
}

\author{
Ketevan Berestova-Gadilia ${ }^{1, *}$ \\ ${ }^{1}$ Ivane Javakhishvili Tbilisi State University, Ph. D. Candidate in Law, 1 Ilia Chavchavadze Avenue, Tbilisi \\ 0179, Georgia
}

\begin{abstract}
In general there are no many scientific papers on coercive measures determined under Criminal Procedural Code of Georgia. Though, based on aforesaid issue we may not state that aforesaid issues were not subject of controversy and does not include disputable opinions. In this scientific article the author represents legal aspects of sequestration - one of the measures of criminal procedural enforcement. Namely, based on active legislation the author in the article mainly considers essence, importance and application criteria of sequestration as a measure of criminal procedural enforcement. The article also considers achieved and possible results of sequestration as a coercive and enforcement measures and importance of aforesaid results. Article is composed of introduction, three parts and conclusion. Introduction of article refers special recommendation approved by Council of Europe Committee of Ministers in September 17, 1987 under that Parliament of Georgia approved Criminal Procedural Code of Georgia through the third hearing that entered into force from October 10, 2010. Contents of article generally refer legal regulation of sequestration, also emphasizing criteria of tax liability at the time of tax dispute and power criteria of tax authority during the specific tax dispute, also here are reviewed issues of enforcement measures related to disputable tax liability by applying coercive measures under the basis of decision of first instance court.
\end{abstract}

\section{Introduction}

The issue that we desire to be jointly discussed is not at all new. Many articles were referred and written about this issue, with different opinions and estimations... possibly it is impossible to have in detail discussed and completely estimated certain issue in one article, though to our minds the first step is to be inevitably made.

In September 17, 1987 Council of Europe Committee of Ministers approved special recommendation offering to its member states introduction of simplified forms of proceedings and approval of expedited forms of criminal litigations. In October 9, 2009 Parliament of Georgia approved Criminal Procedural Code of Georgia through the third hearing in accordance with the mentioned decision that entered into force from October 10, 2010.

If pursuant to the criminal code or material criminal law is approved the basis of criminal responsibility, there is determined as to which act is criminal and established appropriate punishment or other criminal measures. According to the Criminal Procedural Code are approved rules of offence investigation, criminal prosecution and administration of justice.

Sequestration - in accordance with the approved rule it is one of the types of procedural action, more precisely of procedural enforcement. In order to have prepared certain offences, also for the suppression of offence, appropriately authorized persons of certain bodies apply one of the

\footnotetext{
${ }^{*}$ Corresponding author: qetevanberestova@gmail.com
} 
measures of criminal procedural enforcement - sequestration. Namely, if there are grounded suppositions or sufficient data stating that the property of person convicted for specific offence is obtained illegally, though it is not possible to find it, or if there are data stating that the property will be hidden or spent, the court may sequestrate the property of convicted person or other persons determined under the legislation under the basis of party's solicitation.

\section{Legal scope of sequestration}

In accordance with the Article 151, part I of Criminal Procedural Code of Georgia: in order to have carried out procedural enforcement measure, possible confiscation of property the court may sequestrate property of convicted person, materially responsible for the case or/and related person under the basis of party's solicitation, including bank accounts, if there are data supposing that the property may be hidden or spent or/and the property is obtained through the crime. If there are data stating that the property is obtained through the crime, though it is not possible to investigate it, in this event the court has a right to sequestrate the property that has equal cost of mentioned property (Criminal Procedural Code of Georgia, Article 151, 194, year 2009).

In it is to be noted that in accordance with the conditions mentioned in the same article of aforesaid code, if convicted person is senior official, in this event prosecutor is obliged to solicit at the court on the property of this senior official, including bank account, about sequestration, also termination of obligations undertaken under the agreement concluded in the name of state by senior official, or injunctive relief. Prosecutor is also entitled to pose a question at the court on illegal and groundless sequestration of property.

Under the solicitation of prosecutor the court is also entitled to sequestrate the property of persons determined under criminal procedural legislation if there are sufficient data stating that it is committed by corruptive, raid "member of criminal authority/criminal" under Article 194, part 3, subparagraph "c" of Criminal Code (legalization of illegal incomes (laundering) - organized group, under official condition or by gaining especially gross income), property of convict of considered crime or/and offence is committed related to this property or/and is obtained illegally. ${ }^{2}$

In accordance with the approved rule, the owner or proprietor has no right to sell sequestrated property and also in certain cases, even to use sequestrated property. Herein is to be noted that if the case relates to commercial banks, in accordance with the Law of Georgia "on Commercial Bank Activities" liquidator of commercial bank or special manager is entitled to transfer sequestrated accounts to other commercial bank or/and National Bank of Georgia. Herein is to be also noted that in accordance with the rule approved under the legislation, it is prohibited to have sequestrated certain property. It is of course impossible to have provided detailed list of all kinds of properties in one article, though it is to be noted on separate types, namely, it is not allowed to sequestrate nutrition products, fuel, inventory essential for professional occupation and other items necessary for the person providing essential conditions, also financial collateral and settlement account of important system's participant.In accordance with the Criminal Procedural Code of Georgia, Article 151, part 4 upon decision making on sequestration of property there may be applied provisions of Civil Procedural Code of Georgia unless these contradict Criminal Procedural Code of Georgia [1-4].

\section{Sequestration as coercive measure and sequestration as enforcement measure}

It will be appropriate to have emphasized one more issue for the reader within the frameworks of legal regulation of sequestration, namely, Tax Code of Georgia is the main standard act regulating legal relations in the field of taxation in our country. Article 254 of aforesaid code especially regulates tax liabilities during tax dispute and establishes the limits of the authority of taxation body during the tax dispute. What about sequestration of property, in accordance with the Tax Code the rights on sequestration of property are determined under Articles 241 and 242 
of mentioned code, but during the tax dispute this procedure is regulated under Article 254 of Tax Code. After the change of government the only one technical amendment was made in aforesaid articles, but the contents were not amended. In accordance with Article 241 the Revenue Service may sequestrate person's property without court decision, only in the event of acknowledged tax liability, except property obtained through leasing.

It may be stated with regard to particularly unacknowledged tax liability that Revenue Service has a right to sequestration person's property without court decision, only if there is a danger on property alienation and due to this reason liabilities will be complicated or may not be covered. In this event the Revenue Service is obliged to address court with the petition about statement of sequestration of person's property within 48 hours after the sequestration.

In June 20, 2016 former Minister of Finances of Georgia, Nodar Khaduri stated during TV broadcasting (GDS television) that property right remained as one of the major problems of the economics of Georgia till 2012 and there was adopted law under that without waiting for the second and third instance courts, immediately after the end of the first instance court the property was assigned to state property. One of the first legislative initiations in the Tax Code carried out by new force elected in 2012 were nonfulfillment of compulsory measures on property, until entire completion of litigation.

At the time of governmental change the editorial office of active Tax Code of Georgia enforced disputable tax liability under the basis of the decision of the first instance court by applying compulsory enforcement. Pursuant to the amendment as of December 28, 2012 the period on the termination of liability enforcement is equalized to the course of tax dispute.

Till May 13, 2016 under Article 254, part I of Tax Code during tax dispute the property of tax authority and bank accounts may be sequestrated. Under the basis of normative changes taken place during mentioned period, pursuant to Article 254, part 3, for the purposes of sequestration the person's property and bank accounts were separated (Tax Code of Georgia, Article 254, year 2010). In parallel with the procedure on maintenance of sequestration of property in the same form, pursuant to the court decision it was possible to sequestrate bank accounts during tax dispute, so during the course of tax dispute, decision made by tax authority about sequestration of bank account is subject to court approval within 48 hours (Criminal Procedural Code of Georgia, Article 1541, year 2009).

Property is sequestrated without court decision only in exceptional cases, if it is urgently necessary that is to be by all means approved by court within 48 hours.

\section{Problems of legal regulation of sequestration}

In general, rule of property sequestration determined under Article 151, Part I of Criminal Procedural Code of Georgia was always disputable problem in legal proceeding. Namely, the first sentence of aforesaid article - in order to have carried out procedural enforcement measure, possible confiscation of property the court may sequestrate property of convicted person, materially responsible for the case or/and related person under the basis of party's solicitation, including bank accounts, if there are data supposing that the property may be hidden or spent or/and the property is obtained through the crime - unreasonably limits fundamental right of property guaranteed under Article 19 of Constitution of Georgia. In accordance with aforesaid unreasonable limitation the stated standard considers possibility of person's property sequestration so that the mentioned property may not at all be related to possible offence of convicted person. Above mentioned standard is not completely predictable and sufficiently determined that should be essential constitutional claim of right limiting standard [4-6].

Under the basis of Article 151 of Criminal Procedural Code, the issue on interference in property right is considered disputable for practicians and scientists. In particular this issue is considered not disputable but unjustifiable as there is not met requirement of proportionality principle -constitutional criteria on limitation principal human right under that legislative regulation limiting the right is to be necessary, essential and balanced means for the achievement of lawful public objective. To our minds the problematic is the objective of limitation determined under Criminal Procedural Code - "possible forfeiture of property the coercive measure of criminal procedure". Herein is to be noted that the term "coercive measure of criminal 
procedure" is not interpreted under active Criminal Procedural Code, this term was determined in accordance with the Criminal Procedural Code dated by 1998. So, it is impossible to sequestrate property due to unreal objective and aiming only forfeiture of property.

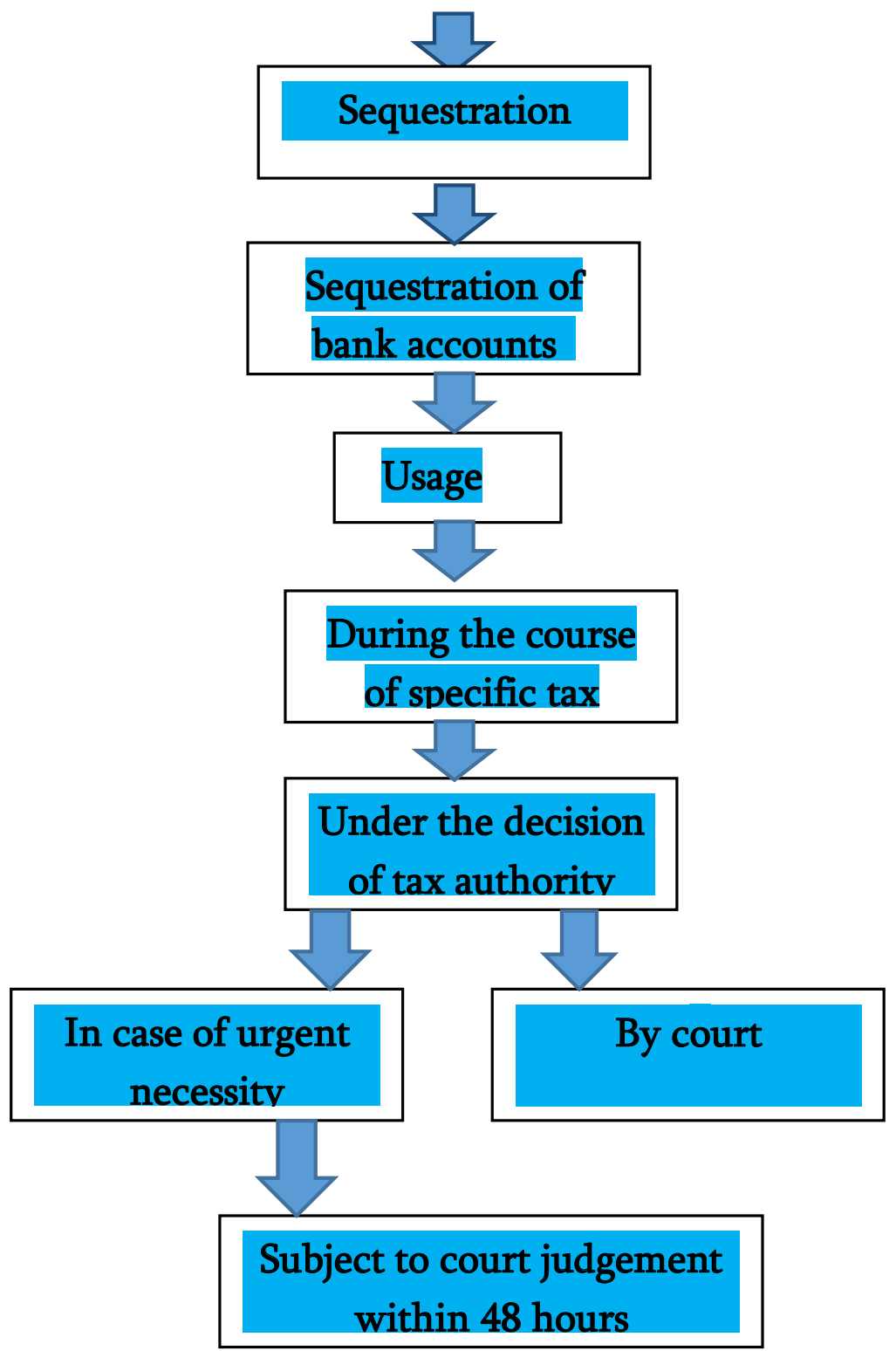

Fig.1. One of the coercive measures determined under Tax Code of Georgia.

In accordance with the Article 52 of Criminal Procedural Code is determined forfeiture of property as one of the types of punishment. Namely, pursuant to the first paragraph of aforesaid article the entity may have confiscated property in the form of punishment, if mentioned property: a) is used or is determined to have used it for the commitment of crime; b) is obtained through the crime (Criminal Code of Georgia, Article 52, year 1998).

Having taken into account aforesaid issue under the basis of disputable standard of Criminal Procedural Code (Article 151 of $\mathrm{CPC}$ ) may have sequestrated not only property related to crime, 
but also the property not at all related with possible offence committed by certain entity and there is only supposed that it will be spent.

So, in our opinions it is impossible to have sequestrated property of accused and person related to him/her "that does not at all relate to criminal activity of person, because if certain owned property is not related to crime, it will not be also possible to forfeit property as a punishment. So, under Criminal Procedural Code of Georgia, Article 151 it is allowed to sequestrate such property that may not be forfeited and thus, legitimate objective may not achieved by limitation that in specific case takes place by sequestration of property.

\section{Conclusion}

Herein is to be noted that pursuant to the bases and procedure approved on the legislative level of sequestration the tax authority is not completely authorized and only in certain cases may act without court decision. Nevertheless the advisability of frequent use of sequestration as one of the measures of enforcement is also often subject of discussion stipulated by the practice of discussion of such issues at the court system. It is regrettable that often the court in advance agrees on sequestration without essential discussion as an application of coercive measure.

In the nearest future in our publications we will again try to bring to reader's attention some problems of legal regulation of certain issues related to sequestration for the discussion and their judgment as a necessity of criminal procedural enforcement.

Ph. D. Candidate in Law Darejan Lekiashvili. Within the frameworks of legal regulation of sequestration, this article also considers criteria of enforcement measures during the course of tax dispute and power criteria of tax authority at the time of specific tax dispute, also here are reviewed issues of enforcement measures related to disputable tax liability by applying coercive measures under the basis of decision of first instance court.

\section{References}

1. Criminal Procedural Code of Georgia

2. Criminal Code of Georgia

3. Tax Code of Georgia

4. G. Latsabidze, Main Specification of the Bail Ensured by Imprisonment in Criminal Procedure Code of Georgia. Law \& World, 10, 45 (2018)

5. B. Bokhashvili, Enforcement and implementation of European Court judgments in Georgia. EHRAC bulletin, 7, 1-2 (2007)

6. T. Dolidze, Practical Recommendations for Effective Justice in Georgia. Law \& World, 12, 35 (2019)

7. M. D. Frederiksen, E. C. Dunn, "Introduction: Ethnographies of Absence in Contemporary Georgia." Slavic Review, 73(2), 307-245 (2014) doi: 10.5612/slavicreview.73.2.307

8. M. Light, "Police Reforms in the Republic of Georgia: The Convergence of Domestic and Foreign Policy in an Anti-Corruption Drive." Policing and Society, 24(3), 318-345 (2014) doi: 10.1080/10439463.2013.784289

9. V. Nordin, G. Glonti, "Thieves of the Law and the Rule of Law in Georgia." Caucasian Review of Internationl Affairs, 1(1), 49-64 (2006) 